\section{Nitrogen isotope signatures of microfossils suggest aerobic metabolism 3.0 Gyr ago}

\author{
F. Delarue ${ }^{1 *}$, F. Robert ${ }^{1}$, K. Sugitani ${ }^{2}$, R. Tartèse ${ }^{3}$, R. Duhamel ${ }^{1}$, S. Derenne ${ }^{4}$
}

Abstract

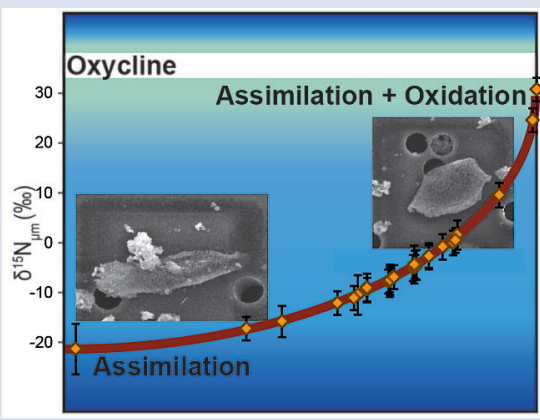

There is compelling evidence for early oxygenation of mid-Archean oceans. However, the biological use of molecular oxygen is still not ascertained. Here we report the nitrogen isotope composition measured in isolated microfossils $\left(\delta^{15} \mathrm{~N}_{\mu \mathrm{m}}\right)$ from the 3.0 billion years old Farrel Quartzite metasediments. We show that the quasi-null bulk $\delta^{15} \mathrm{~N}$ values of Farrel Quartzite organic matter encompass a large ${ }^{15} \mathrm{~N}$ isotopic heterogeneity at the scale of isolated microfossils $\left(-21.6 \%<<\delta^{15} \mathrm{~N}_{\mu \mathrm{m}}<+30.7 \%\right.$ o). Rayleigh fractionation is required to yield such large $\delta^{15} \mathrm{~N}$ variations. Based on these data, we propose a model in which negative $\delta^{15} \mathrm{~N}_{\mu \mathrm{m}}$ values determined on film-like and on spheroidal microfossils are explained by ammonia assimilation in the anoxic deeper levels of the water column, whereas positive $\delta^{15} \mathrm{~N}_{\mu \mathrm{m}}$ values determined on lenticular microfossils were driven by both ammonia assimilation and aerobic oxidation close to the sea surface. Since ammonium aerobic oxidation requires the presence of free molecular $\mathrm{O}_{2}$ within the water column, we further suggest that positive $\delta^{15} \mathrm{~N}_{\mu m}$ values reflect an ocean redox stratification tightly related to $\mathrm{O}_{2}$ production by oxygenic photosynthesisers in a mid-Archean ocean 3.0 Gyr ago.

Received 10 July 2017 | Accepted 10 June 2018 | Published 24 July 2018

\section{Introduction}

The isotopic composition of nitrogen $(\mathrm{N})$ has been investigated in order to tackle questions related to Archean life (Beaumont and Robert, 1999; Pinti et al., 2001; Thomazo et al., 2011; Stueken et al., 2015a). In the present day natural environment, $\mathrm{N}$ is mostly present as di-nitrogen $\left(\mathrm{N}_{2}\right)$, ammonium $\left(\mathrm{NH}_{4}{ }^{+}\right)$, organic $\mathrm{N}$, nitrite $\left(\mathrm{NO}_{2}{ }^{-}\right)$and nitrate $\left(\mathrm{NO}_{3}{ }^{-}\right)$. Within the marine $\mathrm{N}$ cycle, $\mathrm{N}$ compounds are closely coupled in a redox reaction network including specific isotope fractionation processes (Sigman et al., 2009). Accordingly, $\delta^{15} \mathrm{~N}$ of sedimentary organic matter $(\mathrm{OM})$ has been used to infer the evolution of the redox conditions of Archean oceans. For instance, negative $\delta^{15} \mathrm{~N}$ values ranging between -7 and $0 \%$ in the $\mathrm{OM}$ isolated from early Archean rocks (3.6 to $3.2 \mathrm{Ga}$ ) have been interpreted as reflecting (i) anoxic Archean oceans in which microorganisms consumed $\mathrm{N}_{2}$ and $\mathrm{NH}_{4}{ }^{+}$(Beaumont and Robert, 1999) or (ii) a consumption of $\mathrm{N}_{2}$ and $\mathrm{NH}_{4}{ }^{+}$by chemosynthetic bacteria flourishing close to ${ }^{15} \mathrm{~N}$-depleted hydrothermal vents (Pinti et al., 2001; Shen et al., 2006). The late Archean era (2.8 to $2.5 \mathrm{Ga}$ ) is characterised by the occurrence of positive $\mathrm{OM}$ $\delta^{15} \mathrm{~N}$ values (up to $c a .+5 \%$ ) presumably reflecting a rise in the abundance of oxidised N species (Beaumont and Robert,
1999; Garvin et al., 2009; Godfrey and Falkowski, 2009). This suggests that significant free $\mathrm{O}_{2}$ was present in the oceans at that time, which is also supported by several inorganic palaeoredox proxies (Anbar et al., 2007; Reinhard et al., 2009; Stueken et al., 2015b).

Although early and late Archean sedimentary $\delta^{15} \mathrm{~N}$ values suggest a progressive rise in the oxygenation level of Archean oceans, mid-Archean times $(3.2$ to $2.8 \mathrm{Ga}$ ) are characterised by a narrow range of $\delta^{15} \mathrm{~N}$ values close to the $\mathrm{N}$ isotope composition of the present day atmosphere (0\%o), suggesting the dominance of $\mathrm{N}_{2}$ fixing microorganisms (Stueken et al., 2015a). However, complementary geochemical evidence points toward oxygenic photosynthesis occurring as early as ca.3.0 Ga (Crowe et al., 2013; Lyons et al., 2014; Planavsky et al., 2014) and ocean redox stratification ca. 3.2 Gyr ago (Satkoski et al., 2015). If correct, such early oxygenation and ocean redox stratification should be recorded in redox-dependent sedimentary $\delta^{15} \mathrm{~N}$ values, implying in turn that the $\delta^{15} \mathrm{~N}$ values around $0 \pm 2 \%$ o measured on bulk samples might mask isotopic heterogeneities present at smaller scales. To investigate this issue, we have characterised the $\mathrm{N}$ isotope composition of organic microfossils (noted $\delta^{15} \mathrm{~N}_{\mu \mathrm{m}}$ ) isolated from the mid-Archean Farrel Quartzite formation (3.0 Ga; Sugitani et al., 2007) using nanoscale secondary ion mass spectrometry (NanoSIMS).

\footnotetext{
1. Muséum National d'Histoire Naturelle, Sorbonne Université, UMR CNRS 7590, IRD, Institut de Minéralogie, de Physique des Matériaux et de Cosmochimie, IMPMC, 75005 Paris, France

2. Department of Environmental Engineering and Architecture, Graduate School of Environmental Studies, Nagoya University, Nagoya, Japan

3. School of Earth and Environmental Sciences, University of Manchester, M13 9PL Manchester, UK

4. Sorbonne Université, UPMC, CNRS, EPHE, PSL, UMR 7619 METIS, 4 place Jussieu, F-75005 Paris, France

Corresponding author (email: fdelarue@mnhn.fr)
} 


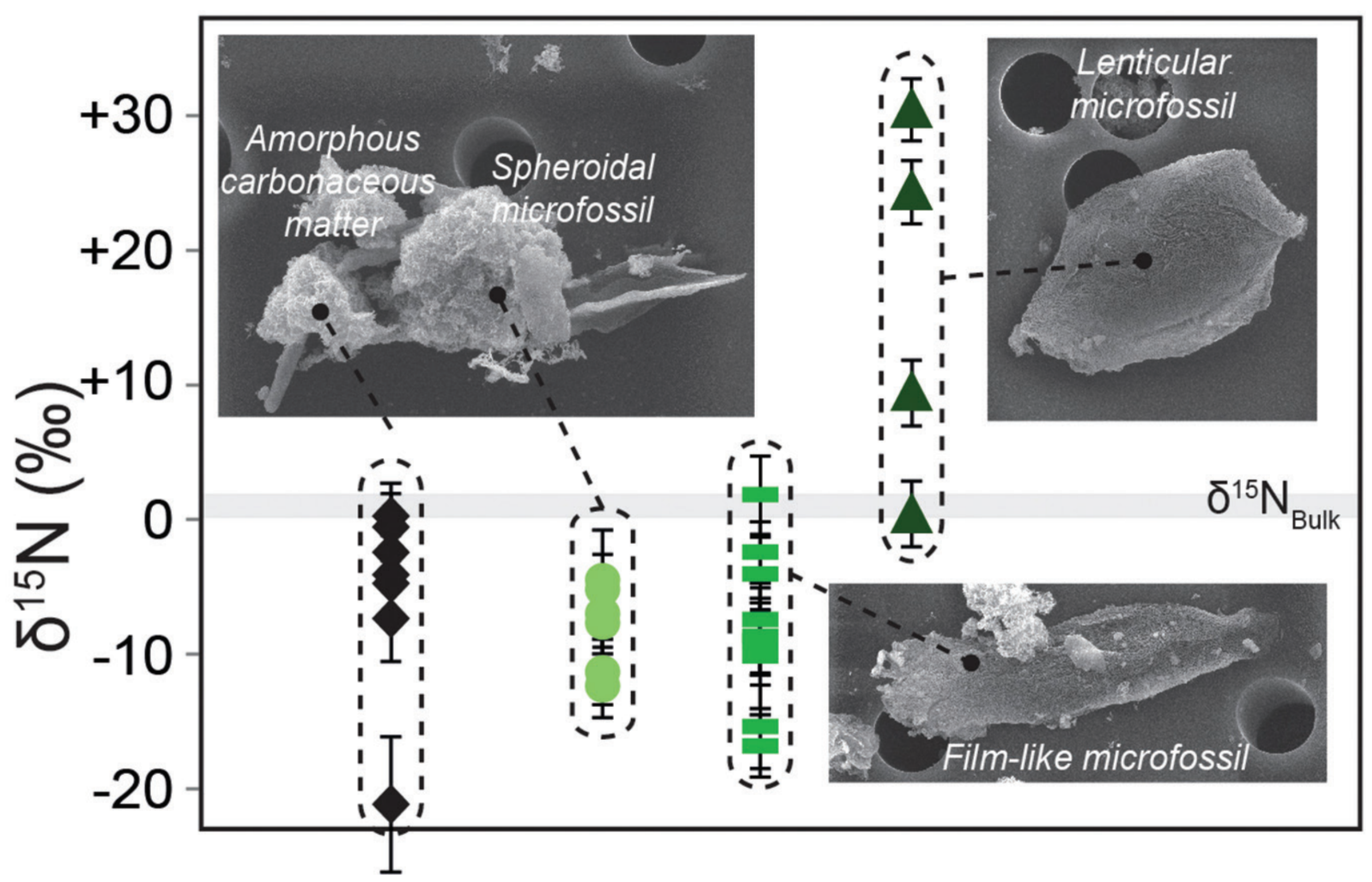

Figure 1 Nitrogen isotopic composition of amorphous carbonaceous matter, and of spheroidal, film-like and lenticular-like microfossils from the $3.0 \mathrm{Ga}$ Farrel Quartzite formation. $\delta^{15} \mathrm{~N}_{\text {Bulk }}$ values are provided for comparison with $\delta^{15} \mathrm{~N}_{\mu \mathrm{m}}$ values.

\section{Material and Methods}

Organic-walled microfossils were isolated by acid maceration using a mixture of hydrofluoric and hydrochloric acids. In the acid maceration residue, we identified lenticular, spheroidand film-like microfossils following the previously reported taxonomy (Sugitani et al., 2007; see also Supplementary Information). In the absence of unequivocal morphological features, the other organic particles were assigned to the "amorphous carbonaceous matter" group.

From a morphological point of view, previous investigations indicate that acid maceration does not affect the morphological integrity of organic-walled microfossils from the Farrel Quartzite (Grey and Sugitani, 2009; Delarue et al., 2017). From a geochemical point of view, preservation of $\mathrm{N}$ content is highly variable across individual microfossils isolated from the Farrel Quartzite (Delarue et al., 2017). This suggests that acid maceration does not cause any significant hydrolysis of $\mathrm{N}$-bearing compounds, which would likely have homogenised the N/C atomic ratios of microfossils through the preferential degradation of chemically labile N organic compounds. Similarly, large variations in $\delta^{15} \mathrm{~N}_{\mu \mathrm{m}}$ are observed among the microfossils, which can only be accounted for by Rayleigh distillation. The latter cannot have occurred during the acid treatment, as $\mathrm{N}$ isotope exchange through Rayleigh distillation cannot take place between solids ( $\mathrm{N}$ in microfossils) and a fluid ( $\mathrm{N}$ dissolved organic compounds in acid solution). Therefore, it is unlikely that acid maceration induced significant modification of both $\mathrm{N} / \mathrm{C}$ atomic ratios and $\mathrm{N}$ isotopic compositions determined at the scale of individual microfossil by NanoSIMS.

\section{Results}

The bulk nitrogen isotope composition (noted $\delta^{15} \mathrm{~N}_{\text {Bulk }}$ ) measured on Farrel Quartzite OM ranges between $+0.3 \%$ o and $+2.2 \%$ (see Supplementary Information; $\mathrm{n}=3$; mean $\delta^{15} \mathrm{~N}_{\text {Bulk }}=1.0 \pm 1.1 \%$; Fig. 1 and Table S-2). These $\delta^{15} \mathrm{~N}_{\text {Bulk }}$ values are consistent with the average $\delta^{15} \mathrm{~N}$ value calculated from all values determined by NanoSIMS on amorphous carbonaceous matter and microfossils isolated from the mineral matrix $\left(\delta^{15} \mathrm{~N}_{\mu \mathrm{m}}=-3.9 \pm 11.5 \%\right.$; $\mathrm{n}=27$; Fig. 1 and Table S-2). However, at the microscale, the $\delta^{15} \mathrm{~N}_{\mu \mathrm{m}}$ values measured on amorphous carbonaceous matter and microfossils vary from $-21.6 \pm 5.1 \%$ o to $+30.7 \pm 2.3 \%$ o. Amorphous carbonaceous matter alone shows $\delta^{15} \mathrm{~N}_{\mu \mathrm{m}}$ values ranging between $-21.6 \pm 5.1 \%$ and $0.0 \pm 2.5 \%$ o $(n=8$; Fig. 1$)$. Film-like $(n=9)$ and spheroid-like microfossils $(n=6)$ exhibit mostly negative $\delta^{15} \mathrm{~N}_{\mu \mathrm{m}}$ values ranging from $-17.2 \pm 2.3 \%$ o to $+1.6 \pm 2.9 \%$, while lenticular microfossils are characterised by positive $\delta^{15} \mathrm{~N}_{\mu \mathrm{m}}$ values ranging from $+0.5 \pm 2.4 \%$ o to $+30.7 \pm 2.3 \%$ o ( $\mathrm{n}=4$; Fig. 1). Based on their nitrogen isotope composition, there is thus a clear discrimination between lenticular microfossils on the one hand and spheroid- and film-like microfossils on the other hand.

\section{Discussion}

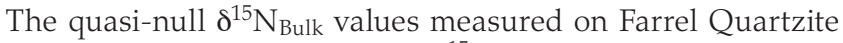
OM hide unexpectedly large $\delta^{15} \mathrm{~N}_{\mu \mathrm{m}}$ variations in isolated microfossils (Fig. 1 and Table S-2). The average of $\delta^{15} \mathrm{~N}_{\mu \mathrm{m}}$ values is close to $\delta^{15} \mathrm{~N}_{\text {Bulk }}$. This observation can be explained if the bulk value integrates a diversity of organic particles with variable $\delta^{15} \mathrm{~N}$. 

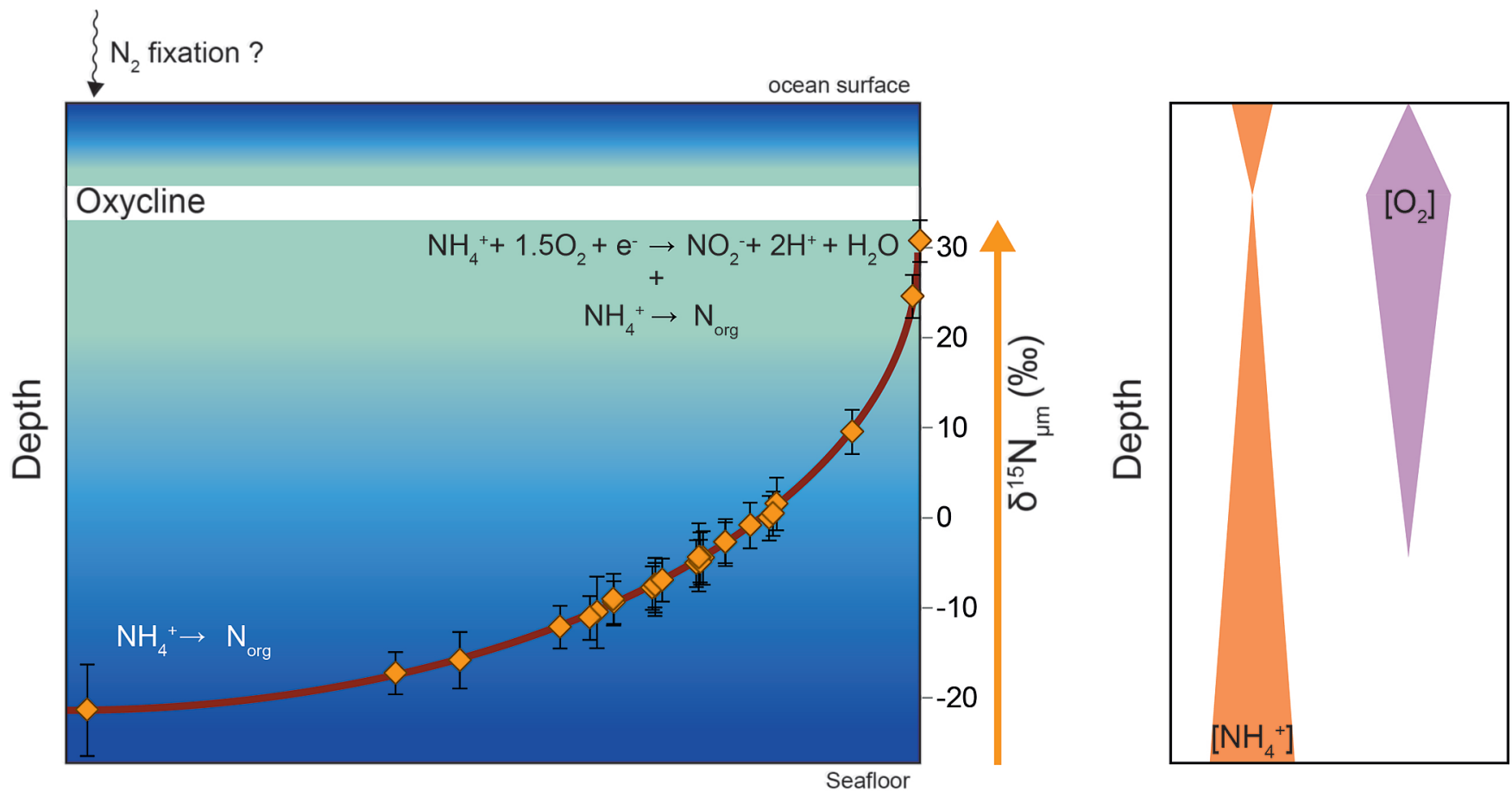

Figure 2 Cartoon illustrating the sedimentary conditions of the Farrel Quartzite formation. The blue gradient in the water column indicates change in $\mathrm{NH}_{4}{ }^{+}$concentration from high (dark) to low (light) concentrations in anoxic zones. $\delta^{15} \mathrm{~N}_{u m}$ values determined at the scale of individual microfossil and organic particle are represented by orange diamonds. In the proposed model, negative $\delta^{15} \mathrm{~N}_{\mu \mathrm{m}}$ values reflect assimilation of $\mathrm{NH}_{4}{ }^{+}$from benthic efflux whereas positive $\delta^{15} \mathrm{~N}_{\mu \mathrm{m}}$ values reflect ${ }^{15} \mathrm{~N}$ Rayleigh distillation of $\mathrm{NH}_{4}{ }^{+}$upward through ammonia oxidation when $\mathrm{NH}_{4}{ }^{+}$concentrations were too low to allow the isotopic fractionation of ammonia assimilation to be expressed (see main text).

Before relating measured $\delta^{15} \mathrm{~N}_{\mu \mathrm{m}}$ values to potential metabolic effects, it is a prerequisite to ensure that biostratonomic and fossilisation processes did not significantly alter the original $\mathrm{N}$ isotopic composition. Biomass degradation can cause $\delta^{15} \mathrm{~N}$ variations of ca. 3-4 \%o (Lehmann et al., 2002), while metamorphism up to greenschist facies, as underwent by the Farrel Quartzite samples, can only induce restricted $\delta^{15} \mathrm{~N}$ modification of up to $\sim 1$ to $2 \%$ (Ader et al., 2006; see Supplementary Information for further details). It thus seems unlikely that secondary processes have largely modified $\delta^{15} \mathrm{~N}_{\mu \mathrm{m}}$ values, which, in turn, may be linked with $\mathrm{N}$ metabolism(s) in the water column.

In the $\mathrm{N}$ cycle, only Rayleigh fractionation has been reported to yield large variations of $\delta^{15} \mathrm{~N}$ values through the partial consumption of $\mathrm{NO}_{3}{ }^{-}$or of $\mathrm{NH}_{4}{ }^{+}$, leaving the residual dissolved inorganic nitrogen (DIN) enriched in ${ }^{15} \mathrm{~N}$ (Sigman et al., 2009). As the $\mathrm{NO}_{3}{ }^{-}$concentration was negligible in Archean oceans (Falkowski and Godfrey, 2008), it is unlikely that partial conversion of $\mathrm{NO}_{3}{ }^{-}$into $\mathrm{N}_{2}$ occurred and gave rise to the observed $\delta^{15} \mathrm{~N}_{\mu \mathrm{m}}$ variations. Thus, only the partial consumption of $\mathrm{NH}_{4}{ }^{+}$seems to be an acceptable mechanism to explain the large variation in $\delta^{15} \mathrm{~N}_{\mu \mathrm{m}}$ values, consistent with an Archean DIN marine reservoir dominated by $\mathrm{NH}_{4}{ }^{+}$ (Thomazo et al., 2011). Three different marine metabolisms (referred to as chemolithoautotrophy) could then be involved in the nitrogen isotope cycle: (i) $\mathrm{NH}_{4}{ }^{+}$assimilation $\left(\mathrm{NH}_{4}{ }^{+} \rightarrow\right.$ $\mathrm{N}_{\text {org }}$ ), (ii) anaerobic $\mathrm{NH}_{4}{ }^{+}$oxidation (anammox; $\mathrm{NH}_{4}{ }^{+}+\mathrm{NO}_{2}$ $\left.\rightarrow \mathrm{N}_{2}+2 \mathrm{H}_{2} \mathrm{O}\right)$ and (iii) aerobic $\mathrm{NH}_{4}{ }^{+}$oxidation $\left(\mathrm{NH}_{4}{ }^{+}+1.5 \mathrm{O}_{2}\right.$ $\rightarrow \mathrm{NO}_{2}{ }^{-}+2 \mathrm{H}^{+}+\mathrm{H}_{2} \mathrm{O}$ ). The $\mathrm{N}$ isotope fractionations (noted $\varepsilon$, with $\varepsilon \approx \delta^{15} \mathrm{~N}_{\mathrm{NH}_{4}}{ }^{+}-\delta^{15} \mathrm{~N}_{\text {Product }}$ ) associated with these processes have been determined experimentally, and range from $+4 \%$ $\leq \varepsilon \leq+27 \%$ for (i) and $+14 \%$ o $\leq \varepsilon \leq+19 \%$ o for (iii), respectively (Hoch et al., 1992; Casciotti et al., 2003). Anammox is not further considered here since its antiquity is still a controversial issue and the resulting $\delta^{15} \mathrm{~N}_{\text {Bulk }}$ remains unknown (Stueken et al., 2016; see also Supplementary Information).
In modern environmental settings, $\delta^{15} \mathrm{~N}$ variations rarely show large variations. However, in the modern Black Sea environment, large $\delta^{15} \mathrm{~N}$ variations ranging from negative up to positive values have been observed to be associated with chemolithoautotrophy along a spatial redox gradient that promotes the progressive oxidation of $\mathrm{NH}_{4}{ }^{+}$in the deep and suboxic level of the Black Sea (Coban-Yildiz et al., 2006). According to this observation, we propose that mineralisation of $\mathrm{OM}$ yielded large amounts of $\mathrm{NH}_{4}{ }^{+}$in the deeper level of the ocean (Fig. 2). Preferential assimilation of ${ }^{14} \mathrm{NH}_{4}{ }^{+}$from this benthic efflux may explain the negative $\delta^{15} \mathrm{~N}_{\mu \mathrm{m}}$ values measured on spheroids and film/filament-like microfossils. The latter are thus likely remnants of benthic microbial mats, in agreement with their morphology (Westall et al., 2006).

We propose that assimilation of $\mathrm{NH}_{4}{ }^{+}$from benthic efflux in the deep water column led to both a decrease in $\mathrm{NH}_{4}{ }^{+}$ concentration and a progressive enrichment in ${ }^{15} \mathrm{NH}_{4}{ }^{+}$in the upper levels of the water column (Fig. 2). Partial $\mathrm{NH}_{4}{ }^{+}$assimilation can yield $\varepsilon$ values down to $-27 \%$ when $\mathrm{NH}_{4}{ }^{+}$concentration is higher than $20 \mu \mathrm{M}$, while lower $\mathrm{NH}_{4}{ }^{+}$concentrations are associated with lower $\varepsilon$ values close to $-4 \%$ (see Stueken et al., 2016 and references therein). In this context, such lower concentrations are unlikely to yield $\delta^{15} \mathrm{~N}_{\mu \mathrm{m}}$ values up to $+31 \%$ o as recorded in the lenticular microfossils. These microfossils are interpreted as remnants of pelagic microorganisms based on both their morphology (Sugitani et al., 2007; Oehler et al., 2010) and their carbon isotope composition (House et al., 2013). We then propose that aerobic $\mathrm{NH}_{4}{ }^{+}$oxidation drove ${ }^{15} \mathrm{~N}$ enrichment of $\mathrm{NH}_{4}{ }^{+}$upward in the water column (Fig. 2). In this scenario, the positive $\delta^{15} \mathrm{~N}_{\mu \mathrm{m}}$ values might be regarded as a redox signal as previously reported (Coban-Yildiz et al., 2006; Granger et al., 2011; Morales et al., 2014). However, to be recorded in $\mathrm{OM}$, aerobic $\mathrm{NH}_{4}{ }^{+}$oxidation should have been coupled with $\mathrm{NH}_{4}{ }^{+}$assimilation, leaving lenticular organic-walled microfossils enriched in ${ }^{15} \mathrm{~N}$ (Fig. 2). 
In view of the $\delta^{13} \mathrm{C}$ (House et al., 2013) and of the present $\delta^{15} \mathrm{~N}$ values along with morphological evidence, this proposed scenario, which combines morphological evidence with $\mathrm{C}$ and $\mathrm{N}$ isotopic data, suggests that life thrived across the entire water column down to the seafloor, and points to the early existence of aerobic metabolism 3 billion years ago. Since aerobic $\mathrm{NH}_{4}{ }^{+}$oxidation implies the occurrence of free dissolved molecular $\mathrm{O}_{2}$ in the water column (Wang and Yang, 2004), this finding echoes previous geochemical arguments pointing toward mid-Archean oxygen oases and, therefore, biological $\mathrm{O}_{2}$ production by oxygenic photosynthesis in stratified mid-Archean oceans (Crowe et al., 2013; Lyons et al., 2014; Planavsky et al., 2014; Satkoski et al., 2015).

\section{Acknowledgements}

This research is supported by the ERC Grant No. 290861 PaleoNanoLife (PI F. Robert). The National NanoSIMS Facility at the MNHN is supported by MNHN, CNRS, Region Ile de France, and Ministère de l'Enseignement supérieur et de la Recherche. Authors are grateful to Marie Balasse and Denis Fiorillo for bulk nitrogen isotopic composition analyses. We also thank three anonymous reviewers, Eva Stueken, Liane Benning and Ariel Anbar for their insightful comments.

Editor: Ariel Anbar

\section{Additional Information}

Supplementary Information accompanies this letter at http:// www.geochemicalperspectivesletters.org/article1816.

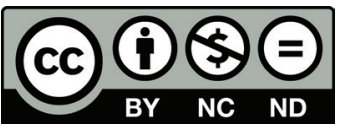

This work is distributed under the Creative Commons Attribution Non-Commercial No-Derivatives 4.0 License, which permits unrestricted distribution provided the original author and source are credited. The material may not be adapted (remixed, transformed or built upon) or used for commercial purposes without written permission from the author. Additional information is available at http://www.geochemicalperspectivesletters.org/ copyright-and-permissions.

Cite this letter as: Delarue, F., Robert, F., Sugitani, K., Tartèse, R., Duhamel, R., Derenne, S. (2018) Nitrogen isotope signatures of microfossils suggest aerobic metabolism 3.0 Gyr ago. Geochem. Persp. Let. 7, 32-36.

\section{References}

Ader, M., Cartigny, P., Boudou, J.P., OH, J.H., Petit, E., Javoy, M. (2006) Nitrogen isotopic evolution of carbonaceous matter during metamorphism: Methodology and preliminary results. Chemical Geology 232, 152-169.

Anbar, A.D., Duan, Y., Lyons, T.W., Arnold, G.L., Kendall, B., Creaser, R.A., Kaufman, A.J., Gordon, G.W., Scott, C., GARVIN, J., BUICK, R. (2007) A whiff of oxygen before the Great Oxidation Event? Science 317, 1903-1906.

BeAumont, V., Robert, F. (1999) Nitrogen isotope ratios of kerogens in Precambrian cherts: a record of the evolution of atmosphere chemistry? Precambrian Research 96, 63-82.

Casciotti, K.L., Sigman, D.M., Ward, B.B. (2003) Linking diversity and stable isotope fractionation in ammonia-oxidizing bacteria. Geomicrobiology Journal 20, 335-353.

Coban-Yildiz, Y., Altabet, M.A., Yilmaz, A., Tugrul, S. (2006) Carbon and nitrogen isotopic ratios of suspended particulate organic matter (SPOM) in the Black Sea water column. Deep-Sea Research Part II-Topical Studies in Oceanography 53, 1875-1892.
Crowe, S.A., Dossing, L.N., Beukes, N.J., Bau, M., Kruger, S.J., Frei, R., CANFiEld, D.E. (2013) Atmospheric oxygenation three billion years ago. Nature 501, 535-538

Delarue, F., Robert, F., Sugitani, K., Tartese, R., Duhamel, R., DERENNE, S. (2017) Investigation of the Geochemical Preservation of ca. 3.0 Ga Permineralized and Encapsulated Microfossils by Nanoscale Secondary Ion Mass Spectrometry. Astrobiology 17, 1192-1202.

FAlKowsKi, P.G., Godfrey, L.V. (2008) Electrons, life and the evolution of Earth's oxygen cycle. Philosophical Transactions of the Royal Society B-Biological Sciences 363, 2705-2716.

Garvin, J., Buick, R., Anbar, A.D., Arnold, G.L., Kaufman, A.J. (2009) Isotopic Evidence for an Aerobic Nitrogen Cycle in the Latest Archean. Science 323, 1045-1048

Godfrey, L.V., FALKOWSKI, P.G. (2009) The cycling and redox state of nitrogen in the Archaean ocean. Nature Geoscience 2, 725-729.

Granger, J., Prokopenko, M.G., Sigman, D.M., Mordy, C.W., Morse, Z.M., Morales, L.V., Sambrotto, R.N., Plessen, B. (2011) Coupled nitrification-denitrification in sediment of the eastern Bering Sea shelf leads to N-15 enrichment of fixed N in shelf waters. Journal of Geophysical Research-Oceans 116.

Grey, K., Sugitani, K. (2009) Palynology of Archean microfossils (c. 3.0 Ga) from the Mount Grant area, Pilbara Craton, Western Australia: Further evidence of biogenicity. Precambrian Research 173, 60-69.

Hoch, M.P., Fogel, M.L., Kirchman, D.L. (1992) Isotope fractionation associated with ammonium uptake by a marine bacterium. Limnology and Oceanography 37, 1447-1459.

House, C.H., Oehler, D.Z., Sugitani, K., Mimura, K. (2013) Carbon isotopic analyses of ca. 3.0 Ga microstructures imply planktonic autotrophs inhabited Earth's early oceans. Geology 41, 651-654.

Lehmann, M.F., Bernasconi, S.M., Barbieri, A., McKenzie, J.A. (2002) Preservation of organic matter and alteration of its carbon and nitrogen isotope composition during simulated and in situ early sedimentary diagenesis. Geochimica et Cosmochimica Acta 66, 3573-3584.

LyONS, T.W., REINHARD, C.T., PLANAVSKY, N.J. (2014) The rise of oxygen in Earth's early ocean and atmosphere. Nature 506, 307-315.

Morales, L.V., Granger, J., Chang, B.X., Prokopenko, M.G., Plessen, B., Gradinger, R., Sigman, D.M. (2014) Elevated N-15/N-14 in particulate organic matter, zooplankton, and diatom frustule-bound nitrogen in the ice-covered water column of the Bering Sea eastern shelf. Deep-Sea Research Part II-Topical Studies in Oceanography 109, 100-111.

Oehler, D.Z., Robert, F., Walter, M.R., Sugitani, K., Meibom, A., Mostefaoui, S., Gibson, E.K. (2010) Diversity in the Archean Biosphere: New Insights from NanoSIMS. Astrobiology 10, 413-424.

Pinti, D.L., Hashizume, K., MATsudA, J. (2001) Nitrogen and argon signatures in 3.8 to $2.8 \mathrm{Ga}$ metasediments: Clues on the chemical state of the Archean ocean and the deep biosphere. Geochimica et Cosmochimica Acta 65, 2301-2315.

Planavsky, N.J., Asael, D., Hofmann, A., Reinhard, C.T., Lalonde, S.V., Knudsen, A., Wang, X.L., Ossa, F.O., Pecoits, E., Smith, A.J.B., Beukes, N.J., Bekker, A., Johnson, T.M., Konhauser, K.O., LYONS, T.W., ROUXEL, O.J. (2014) Evidence for oxygenic photosynthesis half a billion years before the Great Oxidation Event. Nature Geoscience 7, 283-286.

Reinhard, C.T., Raiswell, R. SCOTt, C., Anbar, A.D., Lyons, T.W. (2009) A Late Archean Sulfidic Sea Stimulated by Early Oxidative Weathering of the Continents. Science 326, 713-716.

SAtKoski, A.M., Beukes, N.J., LI, W.Q., Beard, B.L., Johnson, C.M. (2015) A redox-stratified ocean 3.2 billion years ago. Earth and Planetary Science Letters 430, 43-53.

SHEN, Y., PINTI, D.L., HASHIZUme, K. (2006) Biogeochemical cycles of sulfur and nitrogen in the archean ocean and atmosphere. Archean Geodynamics and Environments 164, 305-320.

Sigman, D.M., Karsh, K.L., CasciotTi, K.L. (2009) Nitrogen isotopes in the ocean. In: Steele J.H., Thorpe, S.A., Turekian, K.K. (Eds.) Encyclopedia of Ocean Sciences. Academic Press, Oxford, 40-54.

Stueken, E.E., Buick, R., Guy, B.M., Koehler, M.C. (2015a) Isotopic evidence for biological nitrogen fixation by molybdenum-nitrogenase from 3.2 Gyr. Nature 520, 666-669.

Stueken, E.E., Buick, R., Anbar, A.D. (2015b) Selenium isotopes support free O-2 in the latest Archean. Geology 43, 259-262.

Stueken, E.E., Kipp, M.A., Koehler, M.C., Buick, R. (2016) The evolution of Earth's biogeochemical nitrogen cycle. Earth-Science Reviews $160,220-239$. 
Sugitani, K., Grey, K., Allwood, A., Nagaoka, T., Mimura, K., Minami, M., Marshall, C.P., VAn KranendonK, M.J., Walter, M.R. (2007) Diverse microstructures from Archaean chert from the mount goldsworthy-mount grant area, pilbara craton, western australia: Microfossils, dubiofossils, or pseudofossils? Precambrian Research 158, 228-262.

Thomazo, C., Ader, M., Philippot, P. (2011) Extreme ${ }^{15} \mathrm{~N}$-enrichments in 2.72-Gyr-old sediments: evidence for a turning point in the nitrogen cycle. Geobiology 9, 107-120.

WANG, J.L., YANG, N. (2004) Partial nitrification under limited dissolved oxygen conditions. Process Biochemistry 39, 1223-1229.

Westall, F., de Ronde, C.E.J., Southam, G., Grassineau, N., Colas, M., COCKelL, C.S., LAMMER, H. (2006) Implications of a 3.472-3.333 Gyr-old subaerial microbial mat from the Barberton greenstone belt South Africa for the UV environmental conditions on the early Earth. Philosophical Transactions of the Royal Society B-Biological Sciences 361, 1857-1875. 